\title{
Detection and epidemiological progress of quiescent avocado diseases
}

\section{Ivan Herman Fischer ${ }^{*}$ ([) Matheus Froes de Moraes $^{2}$ Ana Carolina Firmino ${ }^{3}$ Lilian Amorim ${ }^{4}$}

\author{
${ }^{1}$ Agência Paulista de Tecnologia dos Agronegócios (APTA), Polo Regional Centro Oeste, 17030-000, Bauru, SP, Brasil. E-mail: ihfische@apta.sp.gov.br. \\ ${ }^{*}$ Corresponding author. \\ ${ }^{2}$ Faculdades Integradas de Bauru (FIB), Bauru, SP, Brasil. \\ ${ }^{3}$ Faculdade de Ciências Agrárias e Tecnológicas, Universidade Estadual Paulista "Julio de Mesquita Filho" (UNESP), Dracena, SP, Brasil. \\ ${ }^{4}$ Departamento de Fitopatologia e Nematologia, Universidade de São Paulo (USP), Escola Superior de Agricultura "Luiz de Queiroz", \\ Piracicaba, SP, Brasil.
}

\begin{abstract}
One of the major problems in the commercialization of avocados is the incidence of postharvest diseases, especially anthracnose (Colletotrichum spp.) and stem-end rot (Lasiodiplodia theobromae, Fusicoccum aesculi and Neofusicoccum spp.). As there is a lack of epidemiological information on these pathosystems, the objective of this study was to establish a method to detect quiescent infections and characterize their temporal progression and spatial pattern in a commercial orchard. Detection of quiescent infections was evaluated in flowers and fruits that were immature and in commercial harvest stage, treated with paraquat, ethrel or water. Treatment of flowers and immature fruits with paraquat led to rapid detection of Colletotrichum spp. In two seasons of a 'Hass' avocado orchard, the incidence of diseases was evaluated from open flowers to fruit harvest, totaling 11 evaluations at biweekly intervals. When fruits reached the harvest stage, the spatial distribution of diseased fruits in the trees was evaluated by means of dispersion index and modified Taylor's law. Considering the evaluation of temporal disease progression, anthracnose was the most important disease, presenting a high initial incidence of 60 and $86 \%$ diseased flowers in the two seasons, respectively, while fruits showed an average disease incidence of 70 and $87 \%$, respectively. Stem-end rot was observed only in fruits since the beginning of their development and presented low incidence ( $<8 \%$ fruits), significantly inferior to that of anthracnose. The diseases showed random dispersion within the trees, indicating that their initial inoculum is evenly distributed in the plants. Key words: Persea americana, postharvest rot, epidemiology.
\end{abstract}

Detecção e progresso epidemiológico de doenças quiescentes do abacate

RESUMO: Um dos grandes problemas na comercialização de abacates é a incidência de doenças pós-colheita, principalmente a antracnose (Colletotrichum spp.) e as podridões pedunculares (Lasiodiplodia theobromae, Fusicoccum aesculi e Neofusicoccum spp.). Em função da carência de informações epidemiológicas sobre esses patossistemas, objetivou-se estabelecer um método para detectar infecções quiescentes e caracterizar o progresso temporal e o padrão espacial dessas doenças em pomar comercial. A detecção de infecções quiescentes foi avaliada em flores e em frutos imaturos e no ponto de colheita comercial, tratados com paraquat, ethrel ou água. O tratamento de flores e frutos imaturos com paraquat propiciou uma rápida detecção de Colletotrichum spp. Em duas safras de um pomar de abacate 'Hass', avaliou-se a incidência das doenças a partir das flores abertas até a colheita dos frutos, totalizando 11 avaliações em intervalos quinzenais. Quando os frutos alcançaram o ponto de colheita, avaliou-se a distribuição espacial de frutos doentes nas árvores por meio do indice de dispersão e da lei de Taylor modificada. Na avaliação do progresso temporal das doenças, a antracnose foi a mais importante, apresentando elevada incidência inicial, com 60 e 86\% das flores doentes nas duas safras, enquanto que os frutos apresentaram médias de 70 e $87 \%$ de incidência da doença, respectivamente. As podridões pedunculares foram constatadas em frutos desde o início de seu desenvolvimento e apresentaram baixas incidências (<8\% de frutos), significativamente inferior à de antracnose. As doenças apresentaram dispersão ao acaso dentro das árvores, indicando que o inóculo inicial das doenças está distribuído de maneira uniforme nas plantas.

Palavras-chave: Persea americana, podridões pós-colheita, epidemiologia.

\section{INTRODUCTION}

The avocado (Persea Americana Mill.), which belongs to the family Lauraceae, is a fruiting tree that adapts very well to the subtropical climate in Brazil. Its cultivar 'Hass', of small size and high oil content, has shown increasing production in recent years; it is destined especially for exportation but has presented an annual increase in the national market.
However, as a climacteric fruit, the avocado is highly perishable and susceptible to post-harvest diseases, which devalue the fruits, constituting a barrier to commercialization (DAIUTO et al., 2010).

Anthracnose and stem-end rots are defined as quiescent diseases since the infection occurs during fruit development but symptoms only appear during ripening, which is due to the physiological conditions imposed by this host. Thus, fruits are apparently 
healthy at harvest but can manifest symptoms of these diseases during storage and commercialization. During the quiescent infection, temporary fungal growth inhibition may occur in any stage of the process, from spore germination to colonization (PRUSKY, 1996). For control, the magnitude of quiescent infections in the orchard should be learnt, but early detection of quiescent pathogens depends on techniques that modify the fruit physiology, allowing the expression of symptoms. There is a methodology already available to detect quiescent infection by Colletotrichum spp. in mango (PARAMASIVAN et al., 2009), papaya (SILVA, 2010) and guava (FISCHER et al., 2017), as well as by Botryosphaeria dothidea in apples (VALDEBENITO-SANHUEZA et al., 2005), which consists in treating the fruits with ethrel (ethylene precursor) or paraquat. Ethylene promotes fruit ripening, leading to biochemical and physiological changes necessary for the fungus to pass through the quiescence stage and colonize the fruit. Subsequently, symptoms of the diseases rapidly manifest (PRUSKY et al., 1996). Paraquat in turn induces lipid peroxidation and membrane integrity loss (DODGE, 1971), leading to fruit senescence and expression of disease symptoms.

Anthracnose is considered one of the most important diseases affecting avocado trees in all producing countries (DANN et al., 2013). In São Paulo State, Brazil, anthracnose is the major post-harvest disease in 'Hass' avocados, showing average incidence of $62.7 \%$ (FISCHER et al., 2018). This disease is predominantly caused by species of Colletotrichum gloeosporioides complex; although, $C$. acutatum and $C$. boninense complexes have already been reported in other countries, such as Mexico (SILVA-ROJAS \& ÁVILA-QUEZADA, 2011). Characterization of 30 Colletotrichum isolates from avocado, in São Paulo State, detected only species of $C$. gloeosporioides complex (TOZZE JÚNIOR et al., 2015). Anthracnose is particularly important in fruits; although, the pathogen can also infect leaves, flowers and branches without causing damage to the culture. Symptoms in fruits are typical and start as small, circular, brown-to-black dots of approximately 6-13 $\mathrm{mm}$ diameter. Lesions tend to evolve, reaching part of the fruit or causing complete necrosis. Under high humidity conditions, a fungal spore mass of salmon-pink coloration forms in the center of the lesion (DANN et al., 2013).

Stem-end rots of avocados, caused especially by pathogens of the family Botryosphaeriaceae, can be initially misidentified or even occur in association with anthracnose (DANN et al., 2013). In a recent survey carried out with 'Hass' avocados in São Paulo State, the incidence of lasiodiplodia (Lasiodiplodia theobromae) and fusicocum/neofusicocum rots reached 11.8 and $6.6 \%$, respectively (FISCHER et al., 2018). Of 15 isolates of Fusicoccum/Neofusicoccum spp. from avocado trees, 11 were identified as Neofusicoccum parvum and the remaining ones as Fusicoccum aesculi (FIRMINO et al., 2016). Other species of pathogens of the family Botryosphaeriaceae were already reported causing rot in avocados, like $N$. luteum in California (TWIZEYIMANA et al., 2013). Symptoms in fruits due to lasiodiplodia or fusicocum/ neofusicocum rots are similar and characterized as dark necrosis which begins in the stem region with the production of grayish mycelium on the surface of the fruit showing necrosis.

Pathogens that cause quiescent diseases in avocados survive in mummified fruits, cankers, branches and dry leaves and are spread through the wind and the splash of rain (DANN et al., 2013; SHULHANI \& SHTIENBERG, 2018). In Israel, Colletotrichum sp. was confirmed to survive during the winter in green leaves and branches in the orchard (SHARMA et al., 2017). Epidemiological knowledge of quiescent diseases in avocado is limited but has the potential to provide important information for phytosanitary control. Analyses of temporal progression and spatial pattern of diseased fruits may allow inferences about the dispersal mechanisms of pathogenic agents and provide information about inoculum sources. Based on the lack of epidemiological information about postharvest avocado diseases, the aim of this study was to establish a method to detect quiescent rots and characterize their temporal progression and spatial pattern in a 'Hass' avocado commercial orchard.

\section{MATERIALS AND METHODS}

Detection of quiescent infections in avocado flowers and fruits

To induce the expression of quiescent disease symptoms in avocado flowers and fruits, an assay was conducted under controlled conditions. Open flowers, immature fruits $(0.8 \mathrm{~cm}$ length) and asymptomatic fruits in commercial harvest stage were randomly harvested from five-year-old 'Hass' avocado plants, in the crop season 2013/14 (September 30 ${ }^{\text {th }}$, 2013, October $30^{\text {th }}, 2013$ and February $26^{\text {th }}, 2014$, respectively), from a commercial orchard located in Bauru, São Paulo State (SP), Brazil. Flowers and fruits were superficially disinfested in $0.5 \%$ sodium 
hypochlorite solution for 5 minutes and subsequently washed in running water for excess product removal. The following treatments were applied to flowers and fruits by means of immersion for 1 minute: paraquat (3 g/L) (NORTHOVER \& CERKAUSKAS, 1994), ethrel $(0.1 \mathrm{~g} / \mathrm{L})$ (VALDEBENITO-SANHUEZA et al., 2005) or distilled water (control). Then, each flower and fruit was washed in running water for 3 minutes and individually placed on plastic trays, which were stored under continuous light, at $25{ }^{\circ} \mathrm{C}$ and $80-85 \%$ relative humidity $(\mathrm{RH})$, in an incubation chamber. Incidence of diseases was evaluated, at 5, 10 and 15 days after treatments, based on visual symptoms or presence of reproductive structures of the pathogens under an optical microscope. Experimental design was completely randomized, including ten replicates (plants) and ten flowers or fruits per plant. The treatment most efficient in promoting symptom expression was chosen for the experiment of temporal disease progression in the orchard. For statistical analysis, data were transformed into square root of the number of diseased flowers/fruits $(x)+0.5$ and the averages of each evaluation period were compared according to Tukey's test at 5\% probability.

Pathogens were directly isolated from symptomatic organs to potato-dextrose-agar medium (PDA) and their pathogenicity was tested based on the averages of inoculation and symptom reproduction in asymptomatic avocados in commercial harvest stage. Before inoculation, fruits were superficially disinfested in $0.5 \%$ sodium hypochlorite solution for 5 minutes and subsequently washed in running water. The inoculum consisted of $5 \mathrm{~mm}$-diameter mycelial disks containing structures of fungi cultivated in PDA medium for seven days at $25{ }^{\circ} \mathrm{C}$. Inoculation consisted in depositing one disk on the equatorial region of a fruit previously injured with a sterile histological needle to $3 \mathrm{~mm}$ depth. For each isolate, two equatorial regions of a fruit were inoculated on opposite sides. Then, fruits were kept at $25{ }^{\circ} \mathrm{C}$ and $80-85 \% \mathrm{RH}$ for six days, when occurrence of diseases at the inoculated site was evaluated.

\section{Temporal progression and spatial distribution of quiescent diseases in the orchard}

A commercial field of six-year-old 'Hass' avocado plants, located in Bauru, SP (latitude $22^{\circ} 22^{\prime} 30^{\prime}$ 'S, longitude $49^{\circ} 15^{\prime} 76^{\prime}$ ' $\mathrm{W}$, and altitude 558 meters), had five rows of ten plants each evaluated for temporal progression of quiescent diseases. Evaluation was carried out during the crop seasons 2014/15 and 2015/16, from flowering in September to harvest in February, totaling 150 days for each season. The evaluated orchard had local micro- sprinkler irrigation system and canopy diseases were controlled with trifloxystrobin+tebuconazole $(0.06+0.12 \mathrm{~g} / \mathrm{L})$ applied at floral cluster formation plus three sequential applications of copper oxychloride (2 $\mathrm{g} / \mathrm{L}$ ) at intervals of approximately 45 days, employing a $1250 \mathrm{~L} /$ hectare spray volume.

Flowers and fruits were randomly sampled at 15-day intervals; in the first sampling, only flowers (100) were collected, and in the remaining samplings, fruits (two from each of the fifty plants) were harvested. Samples were superficially disinfested in $0.5 \%$ sodium hypochlorite solution for 5 minutes, washed in running water and subsequently immersed in paraquat solution $(3 \mathrm{~g} / \mathrm{L})$ for 1 minute to induce tissue senescence; and consequently, lead to quiescent infection manifestation. Then, samples were washed in running water for 3 minutes and kept in an incubation chamber, under continuous light, at $25{ }^{\circ} \mathrm{C}$ and $80-85 \% \mathrm{RH}$. Incidence of diseases was evaluated after 12-day storage based on visual symptoms characteristic of the studied diseases and on the presence of conidia of their pathogens under an optical microscope.

The area under the disease progress curve (AUDPC) was calculated based on trapezoid integration and diseases were compared between each other and between years according to Tukey's test at $5 \%$ probability, considering each row of 10 plants one replicate. Meteorological information during the fruiting periods was recorded in a station located at $19.7 \mathrm{~km}$ away from the orchard.

Spatial distribution of the diseases in the plant was evaluated based on fruits in commercial harvest stage that were randomly sampled from 10 plants showing a large number of fruits in the field. Plants that were sampled in the season 2015/16 were not necessarily the same as those sampled in season 2014/15. Each plant was divided into 15 quadrats, and five fruits were harvested per quadrat (MADDEN \& HUGHES, 1995). Then, disease distribution maps were elaborated for each plant and the dispersion index was calculated based on the equation: $D=$ $V_{\text {obs }} / V_{\text {bin }}$, with $V_{\text {obs }}=\left[(X i-\mathrm{n} p)^{2} / \mathrm{n}^{2}(\mathrm{~N}-1)\right]$ and $V_{\text {bin }}=p(1-$ $p) / \mathrm{n}(10)$, where $V_{\text {obs }}$ is the observed variance, $V_{\text {bin }}$ is the binomial variance, $X i$ represents the number of diseased fruits per quadrat, $n$ is the number of fruits per quadrat, $N$ is the total number of quadrats per plant and $p$ is the probability of a plant showing diseased fruits. Non-randomness was determined according to Chi-square test $\left(\chi^{2}\right)$, considering $\mathrm{N}-1$ degrees of freedom, at $5 \%$ probability. Joint regression analysis of plants (modified Taylor's Law) was conducted by considering the equation $\log \left(V_{\text {obs }}\right)=A+b \log \left(V_{\text {bin }}\right)$,

Ciência Rural, v.49, n.8, 2019. 
where $A$ and $b$ are the parameters calculated by linear regression (MADDEN \& HUGHES, 1995). To define whether parameter $b$ is equal to 1 , t-test was adopted and the parameter estimate and the standard deviation were used. For $b=1$ and $A=0$, distribution is at random, and for $A>0$ or $b>1$, distribution is aggregate. Hypotheses were tested at 5\% probability level.

\section{RESULTS AND DISCUSSION}

\section{Detection of quiescent infection in avocado flowers and fruits}

Neither symptoms nor signs of the causal agents of stem-end rot were detected in avocado flowers or immature fruits. Incidence rates of fusicoccum/neofusicoccum and lasiodiplodia rots in fruits in commercial harvest stage were 3 and $5 \%$, respectively, for paraquat, 5 and $4 \%$ for ethrel, and 3 and $4 \%$ for control treatment, after 15-day storage. In view of such a low incidence, treatments were not statistically compared.

After 5-day incubation, Colletotrichum acervuli and conidia were detected in flowers of avocado plants, showing no differences among treatments. After 10-and 15-day incubation, incidence was $61 \%$ for paraquat, superior to the $41 \%(\mathrm{P}<0.05)$ found for control. Ethrel yielded an intermediate result, not differing from the remaining treatments (Table 1).

Detection of Colletotrichum was superior to $50 \%$ in immature fruits treated with paraquat, differing $(\mathrm{P}<0.05)$ from the remaining treatments after 5- and 10-day incubation. After 15-day storage, the average incidence of anthracnose in avocados was $66 \%$ and there were no significant differences among treatments. For avocados in commercial harvest stage, no significant difference was found among treatments with paraquat, ethrel and water. The average incidence of anthracnose for these fruits after 15-day storage was $72.3 \%$ (Table 1), which evidences that using the products paraquat and ethrel does not lead to under or overestimation of anthracnose incidence data in avocados.

Fifty isolates of Colletotrichum spp. were obtained from immature fruits and had their pathogenicity proven in inoculated fruits (Figure 1), thus ruling out the possibility of isolating saprophytic Colletotrichum species.

According to the present results, the herbicide paraquat can be recommended for rapid and accurate detection of quiescent infections by Colletotrichum spp. in flowers and immature fruits and can contribute to the disease control measures to be adopted by the farmer. Such data are important not only for epidemiological studies, but also for identifying the need of post-harvest eradicating treatments in case of a high rate of the disease is detected in immature stages. Treatment of mango fruits with paraquat led anthracnose symptoms to manifest 4-5 days earlier, which helped decisions regarding storage period, exportation and fruit offer in the Indian local market (PARAMASIVAN et al., 2009). Immature guavas treated with paraquat and ethrel showed Colletotrichum conidia after 5-day incubation, i.e. two days earlier compared to control treatment (FISCHER et al., 2017). However, production and commercialization of the herbicide paraquat will be forbidden in Brazil from September $22^{\text {nd }}, 2020$ (ANVISA, 2018). Differently from guava (FISCHER et al., 2017) and papaya (SILVA, 2010), for avocado anthracnose detection was not favored by ethrel. Ethylene stimulates conidial germination and appressorium formation in Colletotrichum (PRUSKY et al., 1996). However, this hormone neither activates the development of anthracnose lesions nor favors their growth since the concentration of the antifungal

Table 1 - Incidence (\%) of anthracnose in open flowers, immature fruits $(0.8 \mathrm{~cm}$ length) and fruits in commercial harvest stage of 'Hass' avocados, subjected to different post-harvest treatments during 15 -day storage at $25{ }^{\circ} \mathrm{C}$.

\begin{tabular}{|c|c|c|c|c|c|c|c|c|c|}
\hline \multirow[t]{3}{*}{ Treatment } & \multicolumn{9}{|c|}{ 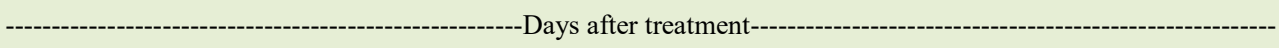 } \\
\hline & 5 & 10 & 15 & 5 & 10 & 15 & 5 & 10 & 15 \\
\hline & \multicolumn{3}{|c|}{------------------Flowers---------------- } & \multicolumn{3}{|c|}{---------Immature fruits--------- } & \multicolumn{3}{|c|}{----------Fruits at harvest point---------- } \\
\hline Paraquat & $45 \mathrm{a}$ & $61 \mathrm{a}$ & $61 \mathrm{a}$ & $53 \mathrm{a}$ & $58 \mathrm{a}$ & $66 \mathrm{a}$ & $0 \mathrm{a}$ & $16 \mathrm{a}$ & $76 a^{1}$ \\
\hline Ethrel & $31 \mathrm{a}$ & $49 a b$ & $49 \mathrm{ab}$ & $3 \mathrm{~b}$ & $28 \mathrm{~b}$ & $64 \mathrm{a}$ & $0 \mathrm{a}$ & $20 a$ & $75 \mathrm{a}$ \\
\hline Control & $28 \mathrm{a}$ & $41 \mathrm{~b}$ & $41 \mathrm{~b}$ & $3 \mathrm{~b}$ & $30 \mathrm{~b}$ & $68 \mathrm{a}$ & $0 \mathrm{a}$ & $18 \mathrm{a}$ & $66 \mathrm{a}$ \\
\hline CV(\%) & 24.5 & 17.5 & 17.5 & 16.5 & 16.1 & 8.3 & 0.0 & 16.9 & 5.8 \\
\hline
\end{tabular}

${ }^{1}$ Data followed by the same letter in the column do not differ from each other by the Tukey's test at $5 \%$ probability. Original data transformed into root $\mathrm{x}+0.5$. 


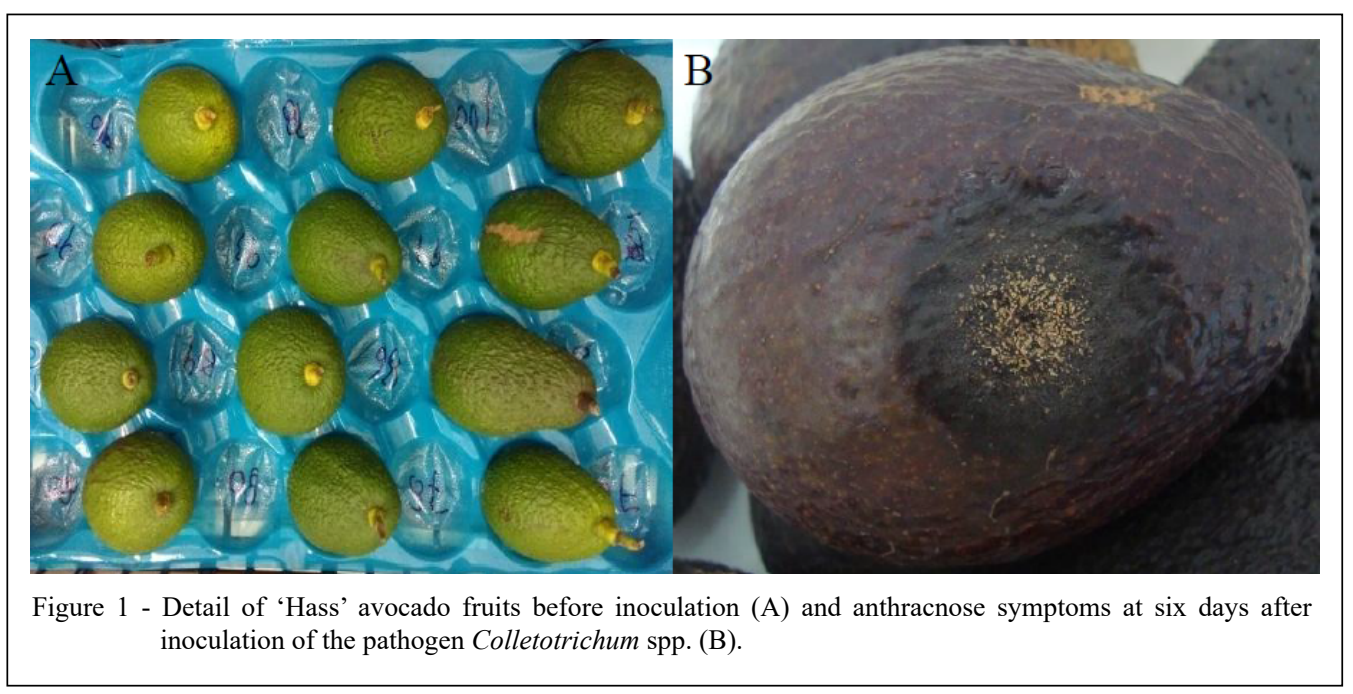

compound diene remains high in immature avocados even after ethylene application (PRUSKY et al., 1996).

Temporal progression and spatial distribution of quiescent diseases in the orchard

In the first crop season, accumulated precipitation was $852.4 \mathrm{~mm}$, average temperature was $25 .{ }^{\circ} \mathrm{C}$, maximum average temperature was $31.4{ }^{\circ} \mathrm{C}$ and minimum average temperature was $18.9^{\circ} \mathrm{C}$. In the second crop season, accumulated precipitation was $1595.0 \mathrm{~mm}$, average temperature was $25.7^{\circ} \mathrm{C}$, maximum average temperature was $31.6{ }^{\circ} \mathrm{C}$ and minimum average temperature was $19.7^{\circ} \mathrm{C}$.

Incidence of anthracnose varied from 60 to $83 \%$ between the first and the last evaluation of fruits in the first crop season and between 76 and $92 \%$ in the second season (Figure 2). Such higher incidence rate in the season $2015 / 16$, compared to the season

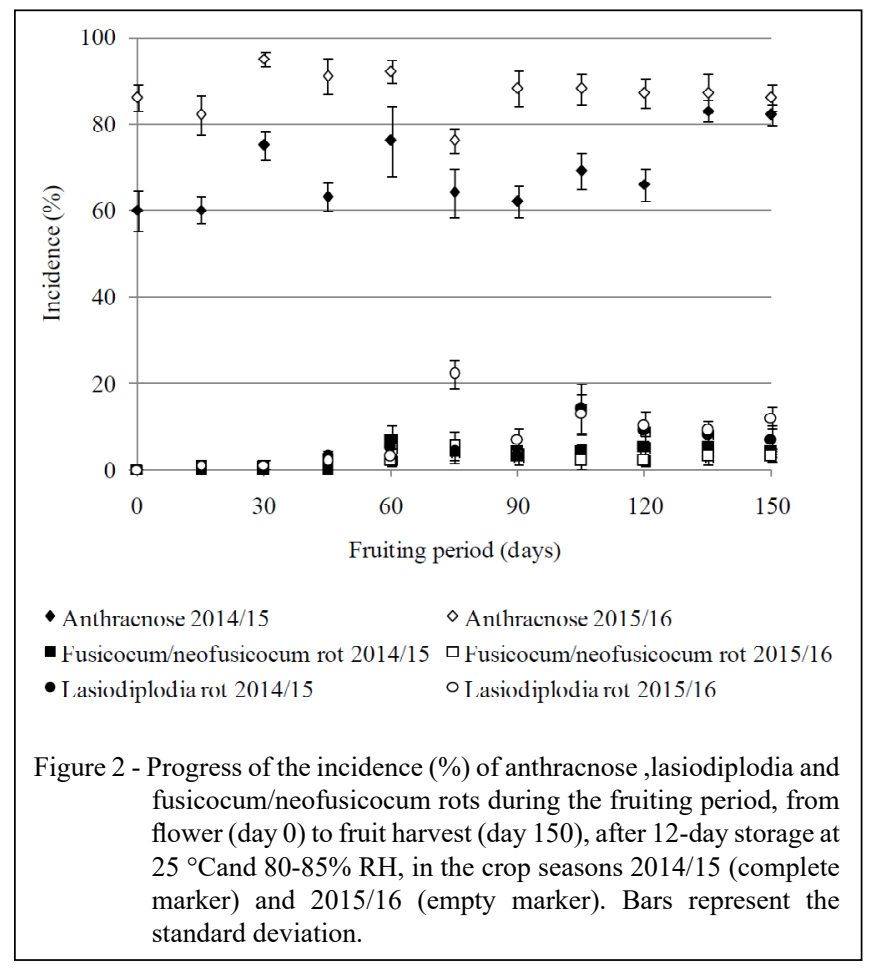

Ciência Rural, v.49, n.8, 2019. 
2014/15 (Table 2), is possibly related to weather conditions more favorable to the disease in the second evaluated season, when precipitation was $87 \%$ greater than that in the previous season. Similarly, increased precipitation has resulted in higher rot levels in Australian avocados (PETERSON, 1978).

$$
\text { Lasiodiplodia and fusicoccum/ }
$$
neofusicoccum rots were less frequent than anthracnose in both seasons; their incidence rates were 6 and $3 \%$, respectively, considering the averages of evaluations and seasons (Figure 2). In the season 2015/16, occurrence of lasiodiplodia rot was greater than that of fusicoccum/neofusicocum rot (Table 2), which was only noted from the third sampling in fruits of $1.8 \mathrm{~cm}$ length. Lasiodiplodia rot could be observed from the fourth sampling period in $3.0-\mathrm{cm}$ fruits in the season $2014 / 15$. In the subsequent season, both pathogens were first found in the second sampling period in $0.8-\mathrm{cm}$ fruits. In the last evaluation, when fruits were in commercial harvest stage, the incidence rates of lasiodiplodia and fusicoccum/neofusicoccum rots were 9.5 and $3.5 \%$, respectively, considering the average of seasons. In 'Pedro Sato' guavas, lasiodiplodia and fusicocum rots were also detected in immature fruits and, similarly to the present study, anthracnose was the most prevalent disease (FISCHER et al., 2017). In some avocado orchards in Chile, the incidence of stem-end rot reached values superior to $20 \%$ (SOTO, 2015). The reasons for the greater occurrence of anthracnose compared to stem-end rot may be associated with the larger number of host plants to Colletotrichum spp. and the high capacity of the pathogen to survive in both cultivated species and wild plants (WEIR et al., 2012). In addition, during the experiments, average temperature kept close to $25{ }^{\circ} \mathrm{C}$ in both crop seasons, which is ideal to the growth of species of $C$. gloeosporioides complex (DANN et al., 2013). The remaining pathogens detected in this study are favored by higher temperatures, such as $L$. theobromae, which has maximum growth within the range $30-35^{\circ} \mathrm{C}$ (SURESH et al., 2017).

The initial incidence of anthracnose was high, with 60 and $86 \%$ of the open flowers diseased in both crop seasons, respectively (Figure 2 ). Similarly to avocado, $50 \%$ guava flowers showed Colletotrichum spp., reaching 100\% fruits of $3 \mathrm{~cm}$ length (FISCHER et al., 2017). The percentage of conidial germination and appressorium formation for C. gloeosporioides do not differ among guavas of different ages (MORAES et al., 2015). This means that the infection can occur at the same intensity, regardless of the maturation stage of fruits. Although, there are no reports about the behavior of conidial germination on the surface of avocados of different ages, the high incidence rates of symptoms observed in this study are indicative of possible occurrence of infection in avocados during flowering and in any period of fruiting.

Progression of anthracnose incidence as a function of fruit maturation stage is almost constant, hardly varying around the average (Figure 2). No epidemiological model that describes the disease progression over time fits to this behavior. A similar situation was already described for anthracnose in 'Kumagai' and 'Pedro Sato' guavas. Besides, there was no significant fit to the models usually employed in epidemiology for anthracnose progression in guavas as a function of the variability in the incidence data (SOARES et al., 2010; FISCHER et al., 2017).

Anthracnose and stem-end rot had random dispersion within each tree, considering all trees, based

Table 2 - Area under the disease progress curve (AUDPC), measured as percentage and obtained from 11 biweekly evaluations (flowering to harvest) of post-harvest diseases in 'Hass' avocados after 12-day storage at $25{ }^{\circ} \mathrm{C}$, under light and $80-85 \%$ RH in the crop seasons 2014/15 and 2015/16.

\begin{tabular}{lcc}
\hline Diseases & Crop season 2014/15 & Crop season 2015/16 \\
& $10,335.0 \mathrm{aB}$ & $13,065.0 \mathrm{aA}^{1}$ \\
Anthracnose & $742.5 \mathrm{bA}$ & $1,110.0 \mathrm{bA}$ \\
Lasiodiplodia rot & $480.0 \mathrm{bA}$ & $337.5 \mathrm{cA}$ \\
Fusicocum/neofusicocum rot & & 7.5 \\
CV(\%) & & \\
\hline
\end{tabular}

${ }^{1}$ Data followed by the same letter, lowercase in the column and upper case in the row, do not differ by the Tukey's test at $5 \%$ probability. 
Table 3 - Dispersion index $(D)$ of the diseases anthracnose and lasiodiplodia and fusicocum/neofusicocum rots in 'Hass' avocados, considering 15 quadrats per plant and five fruits per quadrat. Crop seasons 2014/15 and 2015/16, in an orchard at Bauru, SP.

\begin{tabular}{|c|c|c|c|}
\hline \multirow[t]{2}{*}{ Plants } & \multicolumn{3}{|c|}{ 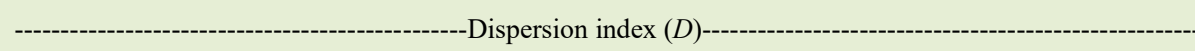 } \\
\hline & Anthracnose & Lasiodiplodia rot & Fusicocum/neofusicocum rot \\
\hline \multicolumn{4}{|c|}{ } \\
\hline 1 & 0.59 & 0.95 & 0.95 \\
\hline 2 & 1.29 & 1.31 & 0.89 \\
\hline 3 & 1.35 & 0.79 & 0.77 \\
\hline 4 & 1.00 & 0.77 & 0.95 \\
\hline 5 & 1.26 & 0.97 & 1.01 \\
\hline 6 & 0.84 & 1.17 & 1.01 \\
\hline 7 & 0.80 & 1.09 & 0.77 \\
\hline 8 & 1.36 & 0.89 & 0.83 \\
\hline 9 & 0.95 & 0.46 & 1.01 \\
\hline 10 & 0.79 & 0.57 & 1.64 \\
\hline \multicolumn{4}{|c|}{ - } \\
\hline 1 & 0.84 & 0.68 & 0.77 \\
\hline 2 & 1.35 & 0.97 & 0.89 \\
\hline 3 & 0.88 & 1.07 & 0.89 \\
\hline 4 & 1.10 & 1.28 & 0.95 \\
\hline 5 & 0.76 & 0.66 & $-^{*}$ \\
\hline 6 & 1.08 & 1.06 & 1.01 \\
\hline 7 & 0.37 & 0.59 & 0.95 \\
\hline 8 & 1.32 & 1.10 & 1.01 \\
\hline 9 & 1.60 & 1.25 & 0.89 \\
\hline 10 & 1.34 & 1.03 & 0.89 \\
\hline
\end{tabular}

${ }^{*}$ When the incidence was zero the observed variance can not be determined (-).

on the dispersion indexes (D) close to 1 (Table 3). These results indicated that the initial inoculum of these diseases is evenly distributed in the plants. Conversely, for citrus black spot (Guignardia citricarpa), diseased fruits had highly aggregate distribution in the tree, which is a result of the inoculum concentration in certain branches of the canopy (SPÓSITO et al., 2008).

The modified Taylor's Law was significant for lasiodiplodia $\left(R^{2}=0.68\right.$, Figure $\left.3 \mathrm{~A}\right)$ and fusicocum/neofusicocum rots $\left(R^{2}=0.88\right.$, Figure 3B) but not significant for anthracnose in the seasons 2014/15 ( $\mathrm{P}=0.853)$ and 2015/16 ( $\mathrm{P}=0.09)$. The values $A=0$ and $b=1$, at $5 \%$ probability according to $t$ test, confirmed the random distribution of fruits showing lasiodiplodia and fusicocum/neofusicocum rots. The random distribution of a disease indicates that the probability of a fruit being diseased is the same, regardless of the presence of other diseased fruits and of its location in the canopy (MADDEN, 1989). For avocado anthracnose, the location of a diseased fruit does not influence the presence or the absence of the disease in other fruits. This behavior shows that the fruit is not an inoculum source throughout its development.

The most probable explanation for the high initial incidence of anthracnose, since flowering, is the presence of already homogeneously distributed inoculum in the area. Colletotrichum sp. was reported in green leaves and branches of avocado plants and its survival in these host organs during the dry summer of Israel occurs by means of a quiescent appressorium (SHARMA et al., 2017). For presenting mucilage around spores, Colletotrichum sp. can also survive for long periods in crop residues (SILVA \& MICHEREFF, 2013). Anthracnose progression rate in guavas was greater $(\mathrm{P}<0.05)$ in a field containing crop residues than in a field without crop residues, 


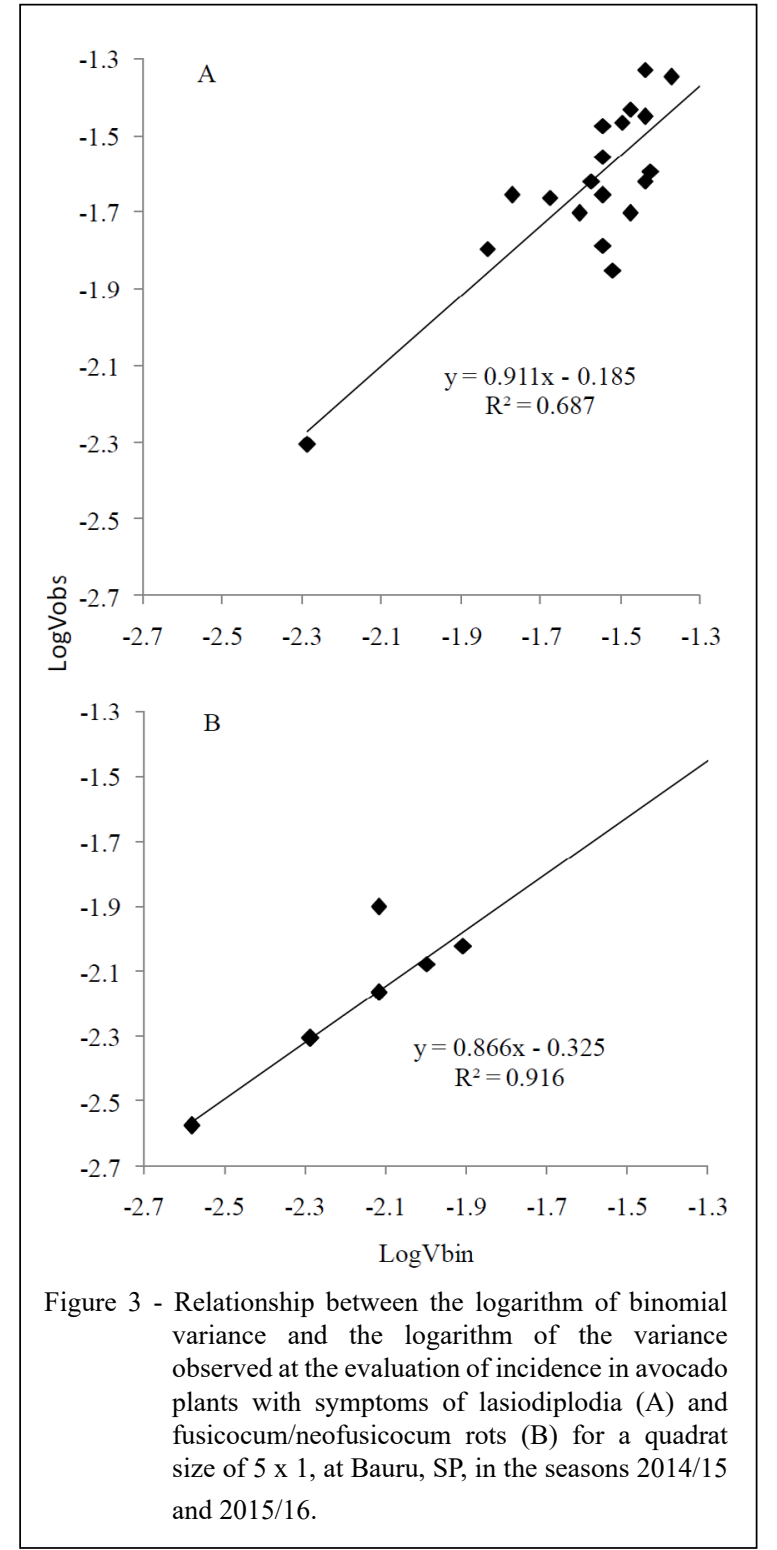

suggesting that the pathogen can survive there (FISCHER et al., 2017). However, there was no consistent reduction in rots after the removal of dry leaves and branches from the canopy of avocado plants (FITZELL, 1987). A $34 \%$ reduction in the incidence of anthracnose was obtained after three applications of azoxystrobin $(0.08 \mathrm{~g} / \mathrm{L})$ during the fruiting period, in addition to the treatments with cupper oxychloride and trifloxystrobin+tebuconazole adopted in the orchard (FISCHER et al., 2018).

In mango trees, Colletotrichum spp. not only can survive for a long period in dry branches and old fruits remaining in the plant or fallen on the ground, but also can have as hosts several wild and cultivated plant species (avocado, cashew etc.) (SILVA \& MICHEREFF, 2013). In guava plants, the stem constitutes a possible inoculum source of Colletotrichum sp. since the pathogen was reported in $25 \%$ stems at one month after the end of the harvest period and in 14\% stems during flowering in the following season (FISCHER et al., 2017). Survival for long periods in the plant itself and in crop residues allows a continuous increase in the incidence of pathogens such as Colletotrichum spp., L. theobromae and Fusicoccum/Neofusicoccum spp. 


\section{CONCLUSION}

Anthracnose was the most frequent disease in 'Hass' avocado. Both anthracnose and stem-end rot had random dispersion within the trees, indicating that the initial inoculum is evenly distributed in the plants. New experiments should be conducted in younger crops to verify the inoculum distribution and frequency in the seedlings.

Considering the need of reducing the initial inoculum, new methods to control the disease during flowering and fruiting should be investigated.

The herbicide paraquat can be employed to early detect anthracnose in avocado flowers and immature fruits, but studies with different products must be conducted since the use of paraquat will no longer be allowed from September $22^{\text {nd }}, 2020$.

\section{ACKNOWLEDGMENTS}

The authors would like to thank Fundação de Amparo à Pesquisa do Estado de São Paulo (FAPESP) (Proc. 2014/11897-4) for the financial support and Jaguacy Farm for making the orchard available.

\section{DECLARATION OF CONFLICT OF INTERESTS}

The authors declare no conflict of interest. The founding sponsors had no role in the design of the study; in the collection, analyses, or interpretation of data; in the writing of the manuscript, and in the decision to publish the results.

\section{AUTHORS' CONTRIBUTIONS}

All authors contributed equally for the conception and writing of the manuscript. All authors critically revised the manuscript and approved of the final version.

\section{REFERÊNCIAS}

ANVISA. Regularização de Produtos - Agrotóxicos. Brasília, 19 jun. 2018. Available from: http://portal.anvisa.gov.br/registrose-autorizacoes/agrotoxicos/produtos/reavaliacao-de-agrotoxicos. Accessed: Jan. 31, 2019

DAIUTO, E.R. et al. Respiratory tax of avocado 'Hass' submitted to different physical treatments. Revista Iberoamericana de Tecnologia Postcosecha, v.10, p.101-109, 2010. Available from: $\quad<$ http://www.redalyc.org/articulo.oa?id=81315091006>. Accessed: Mar. 30, 2018.

DANN, E.K. et al. Foliar, fruit and soil borne diseases. In: SCHAFFER, B. et al. (Eds.). The avocado: botany, production and uses. Wallingford: CAB Intl. Press, 2013. p.380-423.

DODGE, A.D. The mode of action of bipyridylium herbicides, paraquat and diquat. Endeavour, v.30, p.130-135. 1971.
FISCHER, I.H. et al. Temporal progress and spatial patterns of quiescent diseases in guava influenced by sanitation practices Scientia Agricola, v.74, p.68-76, 2017. Available from: <http:// www.scielo.br/pdf/sa/v74n1/0103-9016-sa-74-01-0068.pdf>. Accessed: Mar. 30, 2018. doi: 10.1590/1678-992x-2015-0425.

FISCHER, I.H. et al. Effect of conventional and alternative products on postharvest disease control in avocados. Revista Brasileira de Fruticultura, v.40, p.1-10, 2018. Available from: $<$ http://www.scielo.br/pdf/rbf/v40n1/0100-2945-rbf-40-1-e-408. pdf $>$. Accessed: Mar. 30, 2018. doi: 10.1590/0100-29452018408.

FIRMINO, A.C. et al. Identification of Fusicoccum species causing rot in avocado fruits. Summa Phytopathologica, v.42, p.100-102, 2016. Available from: <http://www.scielo.br/pdf/sp/ v42n1/0100-5405-sp-42-1-0100.pdf $>$. Accessed: Mar. 30, 2018. doi: $10.1590 / 0100-5405 / 2051$.

FITZELL, R.D. Epidemiology of anthracnose disease of avocados South African Avocado Grower's Association Yearbook, v.10, p.113-116, 1987. Available from: <http://www.avocadosource. com/WAC1/WAC1 p113.pdf>. Accessed: Mar. 30, 2018.

MADDEN, L.V. Dynamic nature of within-field disease pathogen distributions. In: JEGER, M.J. (Ed.) Spatial components of plant disease epidemics. New Jersey: Prentice-Hall, 1989. p. 96-126.

MADDEN, L.V.; HUGHES, G. Plant disease incidence: distributions, heterogeneity, and temporal analysis. Annual Review of Phytopathology, v.33, p.529-564, 1995. Available from: $\quad<$ https://www.annualreviews.org/doi/10.1146/annurev. py.33.090195.002525>. Accessed: Mar. 30, 2018. doi: 10.1146/ annurev.pv.33090195.002525.

MORAES, S.R.G. et al. Prepenetration and penetration of Colletotrichum gloeosporioides into guava fruit (Psidium guajava L.): effects of temperature, wetness period and fruit age. Journal of Phytopathology, v.163, p.149-159, 2015. Available from: $<$ https://onlinelibrary.wiley.com/doi/pdf/10.1111/jph.12294>. Accessed: Mar. 30, 2018. doi: 10.1111/jph.12294.

NORTHOVER, J.; CERKAUSKAS, R.F. Detection and significance of symptomless latent infections of Monilinia fructicola in plums. Canadian Journal of Plant Pathology, Ottawa, v.16, n.1, p.30-36, 1994. Available from: <https:// eurekamag.com/pdf/002/002340690.pdf>. Accessed: Set. 04, 2018. doi: $10.1080 / 07060669409500785$.

PARAMASIVAN, M. et al. Detection of latent infections in mango fruit with herbicides. Archives of Phytopathology and Plant Protection, v.42, p.318-326, 2009. Available from: $<$ https:// www.tandfonline.com/doi/full/10.1080/03235400601069696? scroll $=$ top\&needAccess $=$ true $>$. Accessed: Mar. 30, 2018. doi: $10.1080 / 03235400601069696$.

PETERSON, R.A. Susceptibility of Fuerte avocado fruit at various stages of growth, to infection by anthracnose and stem end rot fungi. Australian Journal of Experimental Agriculture and Animal Husbandry, v.18, p.158-160, 1978. Available from: <https://www.researchgate.net/publication/248889510 Susceptibility_of_Fuerte_avocado_fruit_at_various_stages_of growth to infection by anthracnose_and_stem_end_rot_fungi $>$. Accessed: Mar. 30,2018. doi: 10.1071/EA9780158.

PRUSKY, D. Pathogen quiescence in postharvest diseases. Annual Review of Phytopatology, v.34, p.413- 434, 1996. Available 
from: $\quad<$ https://www.annualreviews.org/doi/abs/10.1146/annurev. phyto.34.1.413?rfr dat $=$ cr pub\%3Dpubmed\&url ver $=$ Z39.88 $2003 \& \mathrm{rfr}$ id $=$ ori $\% 3$ Arid\%3Acrossref.org\&journalCode $=$ phyto $>$. Accessed: Mar. 30, 2018. doi: 10.1146/annurev.phyto.34.1.413.

PRUSKY, D. et al. Effect of the ethylene on activation of lesion development from quiescent infections of Colletotrichum gloeosporioides in avocado fruits. Molecular Plant Microbe Interactions, v.9, p.864-868, 1996. Available from: $<$ https://www.apsnet.org/publications/mpmi/BackIssues/ Documents/1996Articles/Microbe09-864.pdf>. Accessed: Mar. 30, 2018. doi: 10.1094/MPMI-9-0864.

SHARMA, G. et al. Epidemiology, pathology and identification of Colletotrichum including a novel species associated with avocado (Persea americana) anthracnose in Israel. ScientificReports, v.7, p.1-16, 2017. Available from: <https://www.nature.com/articles/ s41598-017-15946-w.pdf $>$. Accessed: Mar. 30, 2018. doi: 10.1038/ s41598-017-15946-w.

SHULHANI, R.; SHTIENBERG, D. Aerial dissemination of Lasiodiplodia theobromae and $L$. pseudotheobromae pycnidiospores. In: The $12^{\text {th }}$ International Epidemiology Workshop (IEW12), 2018, Lillehammer, Norway. Anais.. Lillehammer:NIBIO BOOK, 2018. V.4(9), p.49.

SILVA, C.F.B. Desenvolvimento de métodos de deteç̧ão precoce de infecções quiescentes de Colletotrichum spp. em mamão. 2010. 85f. Tese (Doutorado em Fitopatologia) - Curso de Pós-graduação em Fitopatologia, Universidade Federal de Viçosa.

SILVA-ROJAS, H.V.; ÁVILA-QUEZADA, G.D. Phylogenetic and morphological identification of Colletotrichum boninense: a novel causal agent of anthracnose in avocado. Plant Pathology, v.60, p.899-908, 2011. Available from: <file://C:/Users/ Usu\% $\% 3 \%$ A 1 rio/Downloads/articuloColletotrichumboninense. pdf>. Accessed: Mar. 30, 2018. doi: 10.1111/j.13653059.2011.02452.x.

SILVA, C.F.B.; MICHEREFF, S.J. Biology of Colletotrichum spp. and epidemiology of the anthracnose in tropical fruit trees. Revista Caatinga, v.26, p.130-138, 2013. Available from: <file://C:/Users/ Usu\%C3\%A1rio/Downloads/2895-11434-1-PB.pdf>. Accessed: Mar. 30, 2018.

SOARES, A.R. et al. Progresso temporal de doenças quiescentes em pomar de goiabas 'Kumagai'. In: III WORKSHOP DE
EPIDEMIOLOGIA DE DOENÇAS DE PLANTAS, 2010, Bento Gonçalves, RS. Anais... Bento Gonçalves: Comissão Organizadora, 2010. v.3. p.68.

SPÓSITO, M.B. et al. Spatial pattern of Black spot incidence within citrus trees related to disease severity and pathogen dispersal. Plant Pathology, v.57, p.103-108, 2008. Available from: $<$ https://onlinelibrary.wiley.com/doi/ epdf/10.1111/j.1365-3059.2007.01705.x>. Accessed: Mar. 30, 2018. doi: 10.1111/j.1365-3059.2007.01705.x.

SOTO, S.A. Enfermedades de postcosecha de palta. In: DEFILIPPI, B.B. et al. (Ed.). Optimización de lacalidad de palta 'Hass': herramientas para enfrentar nuevos desafíos. La Cruz: Instituto de Investigaciones Agropecuarias, 2015. p.69-75.

SURESH, V.et al. Effect of culture media and different temperatures on mycelial growth and pycnidial production of Lasiodiplodia theobromae casual agent of mango gummosis. Journal of Mycopathological Research, v.54, p.531-534, 2017. Available from: <file:///C:/Users/Usu\%C3\%A1rio/Downloads/v. suresh.pdf $>$. Accessed: Feb. 01, 2019.

TOZZE JÚNIOR, H.J. et al. Characterization of Colletotrichumspp. isolates associated with fruit trees in the state of São Paulo. Summa Phytopathologica, v.41, p.270-280, 2015. Available from: <http:// www.scielo.br/pdf/sp/v41n4/0100-5405-sp-41-4-0270.pdf $>$. Accessed: Mar. 20, 2018. doi: 10.1590/0100-5405/2021.

TWIZEYIMANA, M. et al. Identification and pathogenicity of fungal pathogens associated with stem-end rot of avocado in California. Plant Disease, v.97, p.1580-1584, 2013. Available from: $<$ https://apsjournals.apsnet.org/doi/pdf/10.1094/PDIS-03-13-0230RE>. Accessed: Mar. 30, 2018. doi: 10.1094/PDIS-03-13-0230-RE.

VALDEBENITO-SANHUEZA, R.M. et al. Detection and epidemiology of white rot on apples. Fitopatologia Brasileira, v.30, p.217-223, 2005. Available from: <http://www.scielo.br/pdf/ $\mathrm{fb} / \mathrm{v} 30 \mathrm{n} 3 / \mathrm{a} 01 \mathrm{v} 30 \mathrm{n} 3 . \mathrm{pdf}>$. Accessed: Mar. 30, 2018. doi: 10.1590/ S0100-41582005000300001.

WEIR, B. et al. The Colletotrichum gloeosporioides species complex. Studies in Mycology, v.73, p.115-180, 2012. Available from: $\quad$ https://ac.els-cdn.com/S0166061614600774/1-s2.0 S0166061614600774-main.pdf?_tid=b8270698-7a20-4424-bcbd0864aecbe76f\&acdnat $=1553021909 \quad 754977 \mathrm{ff} 8 \mathrm{a} 1 \mathrm{~d} 3 \mathrm{c} 1 \mathrm{a} 0 \mathrm{~b} 756$ 9a251824745 >. Accessed: Feb. 07, 2019. doi: 10.3114/sim0011. 